ence is now in operation and soliciting members. Sir Anthony Laughton is the new President, John Huthnance is the Secretary, and David Pugh is the Treasurer. From our side, we welcome this new activity, and will report on Challenger Society activities for our members. We look forward to a close interaction.

There has been a strong interest from other parts of the world as well. When I visited China in 1983, Chinese oceanographers expressed surprise that the U.S. did not have an oceanographic society, as theirs is an important factor in communication.

A brochure outlining the aims and activities of The Oceanography Society was distributed at the Executive Council meeting of the Intergovernmental Oceanographic Commission in Paris in March, 1988, and there was wide-spread interest. A number of delegates agreed to become charter members, and a mailing list of interested personnel was begun. Dale Krause of the United Nations Educational, Scientific \& Cultural Organization's (UNESCO) Marine Division expressed interest in helping developing countries to start their own branches of The Oceanography Society.

Within the U.S., it will be useful and effective for all the groups representing ocean science to work together. Kenneth Spengler of the American Meteorological Society has already been helpful in offering advice in organizational matters. Richard Barber of the American Society of Limnology and Oceanography (ASLO) made a number of useful suggestions. In July, 1987 , Fred Spilhaus of the AGU proposed to me that a council of society presidents be established to meet the needs of ocean sciences. I think that this is an excellent idea, and I have written to the presidents of AGU, ASLO, AMS, and MTS proposing that we have such a meeting to discuss how we can work together.

An apt historical precedent for establishing a new society can be found in the establishment of the American Historical Association in 1884. Prior to that time, historians had been represented by a section in the American Social Sciences Association, which had been founded in 1865. The historians felt that "we are drawn together because we feel there is a new spirit of research abroad - a spirit which emulates the laboratory work of the naturalists. That spirit requires for its sustenance mutual recognition and suggestion among its devotees" (Am. Hist. Rev., 90, 2,1985).

From its small beginning of about 220 members, the association grew to over $11,000 \mathrm{mem}$ bers in 1984. The association has been responsible not only for promoting scholarly work, but also for working with Congress through the National Coordinating Committee for the Promotion of History.

The latter group has been key not only in protecting the funding of the National Endowment for the Humanities, but also for promoting the passage of a bill that reestablished the independence of the National Archives.

There are clearly precedents for The Oceanography Society here, and we would do well to emulate the historians.

We have been aided greatly by donations of time and money from various groups. Particularly I would like to mention Omnet for their help with electronic mail issues: James Worsley of the legal firm of Ober, Kaler, Grimes and Shriver, for providing help and advice in incorporation, tax status and trademarks and copyright; and Norman Martin of the Texas A\&M Sea Grant Program for helping with the design and production of Oceanography Magazine.

Without the many contributors and volunteers who have helped, we never would have made it this far. We could conclude with ad astra per aspera, but better perhaps is ad mare per Societum.

\title{
The Challenger Society
}

While U.S. oceanographers have been active forming The Oceanography Society, a group of marine scientists in the U.K. have been working along similar lines to build an active society for marine scientists there.

The Challenger Society was originally founded in 1903 for the promotion of the study of oceanography. In those days it served as a focus for Edwardian gentlemen interested in oceanography to meet and dine together. In later years the society became more active and less exclusive, but still it had no formal legal basis.

Following discussions with other societies. the members of The Challenger Society decided to work towards full legal status. This has now been achieved, with Sir Anthony Laughton, formerly director of the Institute of Oceanographic Sciences, Deacon Laboratory, as its first president.
Surprizingly, the original society had decided against appointing a president, probably because they were unable to choose between two equally strong candidates.

The society plans a full programme of meetings and a regular newsletter. The possibility of a regular semi-popular journal is also being considered.

These are early days under the new arrangements, but there is considerable enthusiasm within the society, not only to serve the members "interests, but also to support marine science in schools and colleges. We hope that The Challenger Society and The Oceanography Society can work together to achieve common goals. Treasurer, The Challenger Society 